\title{
MORE PROMISES TO KEEP: THE EXPANSION OF CONTRACTUAL LIABILITY SINCE 1921
}

\author{
SHANNON K. O'BYRNE*
}

As part of the Alberta Law Review's Special Edition celebrating the seventy-fifth anniversary of the opening of the Law School in 1921, this article endeavours to trace aspects of the expansion of the enforceability of promises from 1921 to 1996. To provide a general context for subsequent analysis, the author begins by outlining the two main theories underlying contractual liability: consideration-based liability and reliance-based liability. The author goes on to discuss how the grounds for enforcing a promise have now expressly gone beyond the structures of a consideration-based liability to include, in addition, a more fact sensitive approach which looks to reasonable reliance by the promisee as a valid reason to enforce a promise. This contention is illustrated through a discussion of two relatively recent phenomena: the judicial reentrenchment of the doctrine of promissory estoppel and the extension of contractual protection to third party beneficiaries. The author concludes by offering some conclusions as to the extent to which the doctrine of consideration has been eroded.
Dans le cadre de cette édition spéciale de l'Alberta Law Review marquant le soixantequinziéme anniversaire de la fondation de la faculté de droit (1921), le présent article suit certains aspects de l'évolution de la force exécutoire des promesses de 1921 a 1996. Pour fournir un contexte général à l'analyss subséquence, l'auteur commence par décrire les deux théories fondamentales de la responsabilité contractuelle: l'une axée sur la doctrine de la contrepartie, l'autre sur la confiance. $L$ 'auteur examine ensuite comment les motifs d'exigibilité d'une promesse ont maintenant dépassé les règles de l'obligation fondée sur la contrepartie pour inclure, de plus, une approche plus sensible aux faits faisant de la confiance raisonnable de la personne concernée une raison valable de réalisation d'une promesse. Ce point de vue est illustré au cours de l'examen de deux phénomènes relativement récents : la réaffirmation par le judiciaire de la doctrine de préclusion promissoire (ou d'irrecevabilité fondée sur une promesse) et l'extension de la protection contractuelle aux tiers bénéficiaires. L'auteur conclut en proposant certaines conclusions sur l'ampleur de l'érosion de la doctrine de la contrepartie.

\section{TABLE OF CONTENTS}

I. INTRODUCTION ..................... 166

II. THE BATTLE OF THE TWO THEORIES:

CONSIDERATION v. REASONABLE RELIANCE $\ldots \ldots \ldots \ldots 168$

A. CONSIDERATION-BASED LIABILITY $\ldots \ldots \ldots \ldots \ldots 168$

B. RELIANCE-BASED LIABILITY $\ldots \ldots \ldots \ldots \ldots \ldots \ldots 173$

III. MODERN EXAMPLES OF

RELIANCE-BASED LIABILITY $\ldots \ldots \ldots \ldots \ldots \ldots \ldots \ldots 175$

A. PROMISSORY ESTOPPEL $\ldots \ldots \ldots \ldots \ldots \ldots \ldots \ldots 176$

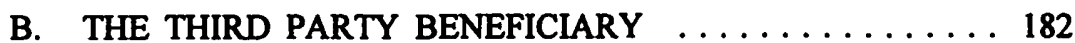

C. VULNERABLE PRECEDENTS $\ldots \ldots \ldots \ldots \ldots \ldots \ldots 185$

IV. CONCLUSION $\ldots \ldots \ldots \ldots \ldots \ldots \ldots \ldots \ldots \ldots \ldots \ldots \ldots$

Assistant Professor, Faculty of Law, University of Alberta. The author would like to thank Mr. James McGinnis of the Edmonton law firm Parlee McLaws and Professor David Percy of the Faculty of Law for their helpful comments. 


\section{INTRODUCTION}

When law students took their seats in 1921 in Professor John Weir's Contracts Law class, ${ }^{1}$ they began to study in the context of cases still analyzed by law students in 1996, including chestnuts like: Carlill v. Carbolic Smoke Ball Co. ${ }^{2}$ on the nature of a unilateral contract; Dickinson v. Dodds ${ }^{3}$ on revocation; Balfour v. Balfour ${ }^{4}$ on intention to create legal relations; and Tweddle v. Atkinson ${ }^{5}$ on privity. Indeed, almost 100 years before the inauguration of the Faculty of Law, the textbook writer Comyn had identified six matters essential to the validity of a contract, which matters maintain complete modern resonance:

(1) a person able to contract; (2) a person capable to be contracted with; (3) a thing to be contracted for; (4) a good and sufficient consideration or quid pro quio; (5) clear and explicit words to express the contract or agreement; (6) the assent of both the contracting parties. ${ }^{6}$

This same classical tradition informs Professor Weir's published works, including his critical analysis of acceptance, frustration, negligence in contractual performance, mistake, risk, and dissolution of contract.?

Whether the classical model taught by Dean Weir was based entirely on English law must remain a matter of some speculation as no course syllabi were produced during this era. Rather, at the end of each class, Weir would simply read out to his students the citation of the cases to be taken up the next day. ${ }^{8}$ It is also the case, however, that during the inter-war years, articles and comments were published by Canadian academics, including Weir, which were somewhat critical of the English model of contract $^{9}$ and some of which looked to American law as a corrective. ${ }^{10}$ For example,

1

My thanks to Dean and Mrs. Bowker for their assistance in providing information regarding John Weir and his important teaching role with the Faculty, during a conversation on August 28, 1996. For further historical information on the early years of the Faculty's operation, see W. Johns, "History of the Faculty of Law" (1980) Alta. L.R. 25th Anniversary Issue 1.

[1893] 1 Q.B. 256 (C.A.).

[1876] 2 Ch D. 463 (C.A.).

[1919] 2 K.B. 571 (C.A.).

(1861), 1 B. \& S. 393 (Q.B.).

Comyn, 2d ed., Comyn's Law of Contracts and Promises (1824) at 2, quoted in W.W. Paine, A Commentary on the Canadian Law of Simple Contracts (Toronto: Carswell, 1914) at 8, n. (a).

Weir's publications in these areas include: "The Sale of Goods Act - Acceptance" (1942-1945)

5 Alta. L.Q. 26; "Frustration of Adventure and Unjust Enrichment" (1929) 7 Can. Bar Rev. 419, reprinted in (1942-1945) 5 Alta. L.Q. 7 [hereinafter "Frustration of Adventure" cited to Alta. L. Q.]; "Contracts-Frustration and Restitutio in Integrum" (1942-1945) 5 Alta. L.Q. 37; "Rights of Third Parties Arising from the Negligent Performance of Contract" (1930) 8 Can. Bar Rev. 451, reprinted in (1942-1944) 5 Alta. L.Q. 28; "Contract-Rights of Third Persons Under Contracts to Which They Are Not Parties" (1942-1945) 5 Alta. L.Q. 77 [hereinafter "Third Persons" cited to Alta. L.Q.]; "Mistake in the Law of Contracts" (1941) 19 Can. Bar Rev. 391, reprinted in (19421945) 5 Alta. L.Q. 107; "Risk in Conditional Sales Agreements" (1929) 7 Can. Bar Rev. 644, reprinted in (1942-1945) 5 Alta. L.Q. 19; "Dissolution of Personal Contract by Death of One of the Contracting Parties" (1942-1945) 5 Alta. L.Q. 40.

- Per Dean Bowker, during a conversation regarding this article on August 28, 1996.

9 For example, Weir is critical of the English doctrine of frustration in "Fnustration of Adventure," supra note 7 at 19, "one cannot help feeling that the Common Law, insofar as this matter is concerned, has now got itself in a position similar to that of a man who has put out to sea in an 
in a 1936 review of Pollock's Principles of Contract, Professor C.A. Wright of Osgoode Hall stated:

[I]t is the writer's opinion that English text-books generally could profit by a more critical approach than one is accustomed to find. There seems no reason to doubt that the English law of contracts might conceivably be improved by some study of American developments..."

Manifesting a similar attitude in a review of the next edition of Pollock's text, Professor John Falconbridge notes that the "value of the book has been notably enhanced" by the editor's frequent references to Williston on Contracts and the American Law Institute's Restatement of the Law of Contracts. ${ }^{12}$ Indeed, a perusal of the Canadian Bar Review and the Alberta Law Quarterly reveals several articles, including some written by Weir, in which the American law of contracts is either noted with approval or at least referenced as part of the author's legal analysis. ${ }^{13}$

One can safely assume, however, that English law would have constituted the centre of Weir's course and this for several reasons noted by Dean W.F. Bowker. ${ }^{14}$ First, Alberta inherited the law of England as at July 15, 1870; second, judgments of the House of Lords and Privy Council were binding in Canada at this time while judgments of the English Court of Appeal were highly persuasive; third, the Colonial Laws Validity Act, $1865^{15}$ was in force until the Statute of Westminster, $1931{ }^{16}$ and fourth, no large body of Canadian cases had yet been established.

Since 1921, the classical model of contract, although unmistakeably constant, has posted some large developments, signalled most dramatically in 1947 with Lord Denning's revitalization of the doctrine of promissory estoppel, ${ }^{17}$ and continuing with sustained judicial efforts to relax the traditional rigours associated with the doctrine of consideration. In short, there is a renewed judicial willingness to enforce promises not only when they have been paid for but also when they have been relied upon. ${ }^{18}$ This

unseaworthy ship equipped with leaky lifeboats."
I am grateful to Professor Percy for this observation

"Review of Principles of Contract, 10th ed." (1936) 14 Can. Bar Rev. 783.

"Review of Principles of Contract, 11th ed. (1942)" (1943) 21 Can. Bar Rev. 513 at 513. As Dean Bowker has observed, such an inclination towards American jurisprudence relates to the fact that several Canadian legal scholars, including Wright, Malcolm MacIntrye, Horace Read and J.B. Milner, all held graduate degrees in law from Harvard.

These include, without seeking to provide an enumeration: C.A. Wright's case comment on Dalhousie College v. Boutilier Estate, "Contracts-Charitable Subscriptions-Consideration" (1935) 13 Can. Bar Rev. 108; his "Case and Comment" (1942) 20 Can. Bar Rev. 710 at 711; and his untitled commentary on certainty, (1939) 17 Can. Bar Rev. 208, at 209. See also "Contract-Rights of Third Persons Under Contracts to Which They Are Not Parties," supra note 7 at 91.

Per Dean Bowker, during a conversation regarding this article on August 28, 1996.

(U.K.), 28 \& 29 Vict., c. 63.

(U.K.), 22 Geo. V, c. 4.

Central London Property Trust Lid. v. High Trees House Lid., [1947] 1 K.B. 130 [hereinafter High Trees].

This trend has been remarked upon by scores of contract law theorists including: $\mathrm{H}$. Collins, The Law of Contract, 2d ed. (London: Butterworths, 1993) at $68 \mathrm{ff}$ J. Cooke \& D. Oughton, The Common Law of Obligations, 2d ed. (London: Butterworths, 1993) at $47 \mathrm{ff}$; see also M. Metzger \& M. Phillips, "The Emergence of Promissory Estoppel as An Independent Theory of Recovery" (1983) 35 Rutgers Law Review 472 at $474 \mathrm{ff}$. But as Atiyah observes in The Rise and Fall of 
marks a deviation from classical contract law theory, with its emphasis on bargain, consensualism and individual freedom, as well as an expansion of an equity-based liability founded on judicially defined notions of fairness, good conscience and the desire to enforce reasonable commercial expectations. ${ }^{19}$

As part of the Alberta Law Review's Special Edition celebrating the seventy-fifth anniversary of the opening of the Law School, this article will endeavour to trace aspects of the expansion of the enforceability of promises from 1921 to 1996. Part II of the article outlines the two main theories underlying contractual liability to provide a general context for subsequent analysis. Part III shows that the grounds for enforcing a promise have now expressly gone beyond the strictures of a consideration-based liability to include, in addition, a more fact-sensitive approach which looks to reasonable reliance by the promisee as a valid reason to enforce a promise. This contention will be illustrated through discussion of two relatively recent phenomena: the judicial re-entrenchment of the doctrine of promissory estoppel and the extension of contractual protection to third party beneficiaries. Part IV offers some conclusions as to the extent to which the doctrine of consideration has been eroded.

\section{THE BATTLE OF THE TWO THEORIES: CONSIDERATION v. REASONABLE RELIANCE}

\section{A. CONSIDERATION-BASED LIABILITY}

The University of Alberta Faculty of Law began its full-time operations in the heyday of classical contract law theory whose:

latent social ideal ... embodies a libertarian state, in which the law maximizes the liberty of individual citizens, encourages self-reliance, and adopts an avowedly neutral stance with regard to permissible

Freedom of Contract (Oxford: Clarendon Press, 1979) at 462, there are many examples in the nineteenth century of a judicial willingness to protect reasonable reliance but that in "all these cases, it came to be felt, somewhat after the end of this period, that the decisions were anomalous." Such an equitable focus for the enforceability of promises may not, in fact, be entirely new. For example, it has been argued by $M$. Horwitz that there was also an equitable foundation for contract law in the pre-commercial days of the eighteenth century, where contracts were enforced according to the "inherent justice or faimess of an exchange." See "The Historical Foundations of Modern Contract Law" (1974) 87 Harvard Law Review 917. Horwitz theorizes that this focus changed by the late eighteenth century with the advent of a market economy and the executory contract. There was, by this time, an increasing separation between contract and natural justice as well as the entrenchment of a formalistic system of rules divorced from the "ancient precepts of morality and equity," ibid. at 955-956. It is worth noting that Horwitz's thesis has been criticized, inter alia by A.W.B. Simpson in "The Horwitz Thesis and the History of Contracts" (1979) 46 University of Chicago Law Review 533 at 539-40 [footnootes omitted]:

Although there is room for judgment here, the suggestion that English law reflected a relatively simple and primitive economy is odd.... England, even in the first half of the eighteenth century, was the greatest trading nation in the world, and its trade was supported by a sophisticated mercantile community well versed in the techniques of shipping, financing, and insuring cargoes around the world. Equally important, England was second to none in the skill and depth of this commercial and industrial infrastructure.... Important regional markets affected a large part of the population no later than the beginning of the century; just feeding and supplying London oriented much of the country towards producing for a market. 
patterns in social life. The law of contract secures these goals perhaps more effectively than any other category of law by facilitating the creation of legal obligations on any terms which individuals freely choose. ${ }^{20}$

Theorists tend to agree that this notion of contract law solidified toward the end of the nineteenth century, ${ }^{21}$ though as Grant Gilmore notes, "the general theory of contract was never as neat and tidy and all-of-a-piece in the real world as it was made to appear in casebook and treatise and Restatement."122

It is this classical theory of contractual liability which elevated the doctrine of consideration as the fundamental test of enforceability, ${ }^{23}$ with consideration itself being rigorously defined in the nineteenth century. ${ }^{24}$ By this time, the informing idea was that before liability could attach, there would have to be a bargained-for exchange: "Each party must promise to give up, or actually give up, some right or liberty specified by the other as the price of the reciprocal undertaking." 25 Similarly, as B. Reiter notes, consideration in its most technical form requires that "the plaintiff must have 'bargained' with the defendant and the defendant must have given the promise sued upon 'in return for' the consideration 'given or promised' by the plaintiff."26 Thus, the presence of consideration acts as a central feature of liability.

Though some struggle was put up by Lord Mansfield who argued for a broader understanding of what promises would be enforceable, ${ }^{27}$ it is incontrovertible that Lord

Collins, supra note 18 at 4-5. It is beyond the scope of this article to discuss the extent to which classical contract law theory kept apace with or properly accounted for the de facto decline in the belief of freedom of contract, discussed by Atiyah as beginning around 1870. For more on this point, see P.S. Atiyah, An Introduction to the Law of Contract, 4th ed. (Oxford: Clarendon Press, 1989) at $17 \mathrm{ff}$.

See e.g. Metzger \& Phillips, supra note 18 at 475; Atiyah, supra note 18 at 681 ; and A. Mason \& S. Gageler, "The Contract" in P. Finn., ed., Essays in Contract (Sydney: The Law Book Company, 1987) 3.

G. Gilmore, The Death of Contract (Columbus: Ohio State University Press, 1974) at 55, quoted in part, by Metzger, ibid. at n. 6.

Collins, supra note 18 at 51 .

Ibid. at 52.

Ibid.

"Contracts, Torts, Relations and Reliance" in B. Reiter \& J. Swan, eds., Studies in Contract Law (Toronto: Butterworths, 1980) 235 at 238.

As E. Farnsworth notes in Contracts (Boston: Little, Brown \& Company, 1982) at 87, Mansfield mounted a "memorable, if short-lived, attack on the doctrine in 1765." In Pillans v. Van Mierop (1765), 3 Burr. 1663, 97 E.R. 1035 at 1038 (K.B.) [hereinafter Pillans], Lord Mansfield states: "I take it, that the ancient notion about the want of consideration was for the sake of evidence only: for when it is reduced into writing, as in covenants, specialities, bonds, \&c., there was no objection to the want of consideration.... In commercial cases amongst merchants, the want of consideration is not an objection." In Pillans, ibid. at 1038, Wilmot J. states that consideration "was made requisite, in order to put people upon attention and reflection, and to prevent obscurity and uncertainty: and in that view, either writing or certain formalities were required.... Therefore it was intended as a guard against rash inconsiderate declarations: but if an undertaking was entered into upon deliberation and reflection, it had activity; and such promises were binding." Mansfield's approach was unequivocally rejected in Eastwood v. Kenyon, [1835-42] All E.R. Rep. 133 at 136 by Denman C.J. who stated:

Lord Mansfield... [is alleged to have] considered the rule of nudum pactum as too narrow, and [to have] maintained that all promises deliberately made ought to be held binding.... 
Skynner's 1778 analysis of contractual liability in Rann v. Hughes came to carry the day and serves as a succinctly accurate account of the foundation of classical contract law theory:

It is undoubtedly true that every man is by the law of nature, bound to fulfil his engagements. It is equally true that the law of this country supplies no means, nor affords any remedy, to compel the performance of an agreement made without sufficient consideration, such agreement is nudum pactum ex quo non oritur actio..... ${ }^{28}$

In the classical tradition then, the very definition of contract is tied to the notion of consideration. ${ }^{29}$ And, unlike the reliance test of enforceability which "has received only halting and partial recognition in English law," the consideration test is firmly entrenched. ${ }^{30}$

Inquiries as to why the doctrine of consideration became so central in the law of contract have been undertaken by numerous scholars with no resulting consensus. ${ }^{31}$ According to $\mathrm{K}$. Sutton, "to search for the true origin of the doctrine of consideration is futile" and further:

[t]he modem view of the origin of the doctrine of consideration appears to be that it grew up by more or less accidental and obscure evolution in the juridical process of fumishing remedies in the action of assumpsit. ${ }^{32}$

Notwithstanding the uncertain origins of consideration, one can safely attribute some of its success to the symbiotic relationship it bears to liberal political theory which seeks to place limits upon the State's role in enforcing "voluntary undertakings"; ${ }^{13}$ to the concomitant value of respecting the will of the parties to be bound, ${ }^{34}$ to the

[Such a] doctrine would annihilate the necessity for any consideration at all, inasmuch as the mere fact of giving a promise creates a moral obligation to perform it. See also discussion in Cooke, supra note 18 at 9.

Rann v. Hughes (1778), 7 T.R. 350n, 101 E.R. 1014n referred to by Farnsworth, ibid. at 88. According to Metzger, supra note 18 at 477 , it was by the mid-to-late nineteenth century that the notion of consideration "began to acquire something like its current meaning: a bargained-for exchange where that which is given in exchange for the promise involves benefit to the promisor or detriment to the promisee" [footnotes omitted]. Collins, supra note 18 at 51 , notes that many textbook writers define contracts with express reference to consideration. Ibid. at 45.

See e.g. A.W.B. Simpson, A History of the Common Law of Contract: The Rise of the Action of Assumpsit (Oxford: Clarendon Press, 1987); and K. Sutton, Consideration Reconsidered: Studies on the Doctrine of Consideration (St. Lucia: University of Queensland Press, 1974). Ibid. at 7.

3) Collins, supra note 18 at 41.

34 For S. Williston, "Freedom of Contract" (1921) 6 Cornell Law Quarterly 365 at 366-69, the will theories of contract resulted as "a corollary of the philosophy of freedom and individualism that the law ought to extend the sphere and enforce the obligation of contract," quoted by James Gordley, The Philosophical Origins of Modern Contract Doctrine (Oxford: Clarendon Press, 1991) at 214. The will theories of contract, according to Gordley ibid. at 162 , were recognized by jurists in the nineteenth century and define contract or promise "in terms of consent, agreement, or expression of will." Atiyah provides a similar account: supra note 20 at $8 \mathrm{ff}$. 
requirements of a market economy ${ }^{35}$ and, just as directly, to the bargain theory of contract. ${ }^{36}$

The bargain theory of contract provides for the enforcement of a promise that has been purchased or otherwise "paid for." As Sutton notes from the Anglo-Australian perspective, "throughout the nineteenth century and persisting into the twentieth century, there is a hardening of the juristic attitude, with insistence being increasingly given to the notion of consideration as the price in return for which the promise is made. ${ }^{137}$ This same trend is observed by American theorists such as Metzger ${ }^{38}$ and Gilmore. ${ }^{39}$

Professor Treitel contends that the bargain theory of contract has never been "expressly adopted by the courts in England" 40 and further, that the bargain theory does not account in any satisfactory way for the fact that English courts acknowledge that nominal consideration is good consideration." Put another way, the doctrine of consideration is not as "rigid and hidebound" as the bargain theory implies..$^{42}$ Further, it is true, as Treitel observes, that the bargain theory does not account for several English cases in which the courts have "invented" consideration, that is, where "they have treated some act or forbearance as consideration quite irrespective of the question whether the parties have so regarded it." ${ }^{13}$ Accordingly, Treitel concludes that the American bargain theory of consideration does not fully describe English jurisprudence:

Collins, supra note 18 at $41 \mathrm{ff}$; Atiyah, supra note 18 at $402-403$ and Atiyah, supra note 20 at 8 ff.

As the American theorist E. Farnsworth notes, while consideration came to be understood as requiring the promisee to give something in exchange for the promise, this gave way, by the end of the nineteenth century, to the requirement that the consideration be "bargained for": supra note 27 at $41 \mathrm{ff}$.

Supra note 31 at 14. As an example, Sutton, ibid. at 15, cites, Dunlop Pneumatic Tyre Co. Ltd. v. Selfridge \& Co. Lid. [1915] A.C. 847 at 855 [hereinafter Dunlop] wherein Lord Dunedin adopts the following definition of consideration: "[a]n act or forbearance of one party, or the promise thereof, is the price for which the promise of the other is bought, and the promise thus given for value is enforceable" [emphasis added]. Note that the bargain theory informs cases dating back from at least 1588 , Sutton, ibid. at 13.

38 Supra note 18 at $477 \mathrm{ff}$.

39 Supra note 22 at $19 \mathrm{ff}$. It has been observed by Mason, supra note 21 at 25 , that the English notion of consideration differs from the American bargain theory because one element in the latter version is that 'nothing can be consideration which is not regarded as such by the parties,' quoting from Phipot v. Gruninger (1870), 14 Wall 570 at 577 . Put another way, it is said by Mason ibid. at 25 that English Courts are more "willing to treat or imply an act or a forbearance as consideration" than their American counterparts. Notwithstanding, English Courts generally do require consideration to be bargained for, as seen in Dunlop, supra note 37. Further, as the Australian High Court in Waltons Stores (Interstate) Pty. Lid. v. Maher (1987), 76 ALR 513 at 522 [hereinafter Waltons] notes, though the bargain theory of consideration "has not been expressly adopted in Australia or England...[i]t may be doubted whether our conception of consideration is substantially broader than the bargain theory." Atiyah, supra note 20 at 135 .

4 "Consideration: A Critical Analysis of Professor Atiyah's Fundamental Restatement" (1976) 50 Aus. L.J. 439 at 440. 
In the United States, the narrow doctrine of consideration is supplemented by a broad doctrine of promissory estoppel which can, in particular, give rise to new causes of action. In England this possibility is generally denied; but the narrow scope of the doctrine of promissory estoppel is counterbalanced by the adoption of a broad definition of consideration. ${ }^{44}$

There are several brief comments to be made on Treitel's assessment. First, there is American case law wherein - the bargain theory notwithstanding - courts have broadened the doctrine of consideration by "inventing" consideration. They do so through the technique of reading an "apparently illusory promise so that it is not illusory." ${ }^{145}$ For example, in Grean \& Co. v. Grean, ${ }^{46}$ at issue was a clause permitting an officer of a corporation to devote such time to the corporation "as he in his sole judgment shall deem necessary." The court determined that this clause required the corporate officer to "act in good faith," such that his promise was not illusory. Through this technique, the court imports obligations into a promise and thereby makes the agreement contractual because there is consideration supporting the promises of the other party in such a case. ${ }^{47}$ Further, there is a documented judicial strategy, observed by Farnsworth, through which courts find an "implied" return promise as consideration for an express one. Again, the outcome is to assure enforceability of the agreement. ${ }^{48}$

Treitel is therefore only partially correct in his assessment. Some differences do, of course, remain between English and American jurisprudence and the bargain theory does not fully account for all instances in which the courts find the presence of consideration. However, the bargain theory stands as a useful account of most judicial decisions regarding consideration in both jurisdictions and undisputably goes to the heart of contractual enforceability.

By way of contrast, and with few exceptions such as proprietary estoppel, reliance has not generally been accepted by the judiciary as a reason to enforce a promise. A classic reaction to the argument that reliance could found liability is the 1933 decision of the Supreme Court of Canada in Dalhousie College v. Boutilier Estate. ${ }^{49}$ In this case, it was found that a charitable subscription was unenforceable for want of consideration; any reliance on the subscriber's promise by Dalhousie University in the form of expenditures would not take the promise out of the realm of nudum pactum because no definite expenditure was authorized or requested by the subscriber. The court stated that:

To hold otherwise would be to hold that a naked, voluntary promise may be converted into a binding legal contract by the subsequent action of the promisee alone without the consent, express or implied, of the promisor. ${ }^{50}$ 
Though the court had to reject four provincial Court of Appeal decisions to rule against Dalhousie University, ${ }^{51}$ its reasoning does confirm the judicial view that reliance by the promisee on a promise could not make the promise a contractual one, by, in essence, bootstrapping. The litmus test followed by the court was bargained-for exchange, pure and simple. Absent this, the consideration is foisted, the promise is gratuitous and the agreement is unenforceable.

\section{B. RELIANCE-BASED LIABILITY}

A reliance-based theory of liability is regarded with profound suspicion by courts bound by the classical tradition, because, as expressed late in the nineteenth century, it "would cut up the doctrine of consideration by the roots, if a promisee could make a gratuitous promise binding by subsequently acting in reliance on it." ${ }^{52}$

But though consideration remained the dominant theory of liability, it was not the only substantive test of enforceability. As Metzger notes, reliance interests were critical factors in the predecessor action of assumpsit, and further, post-revolutionary American contract law "was replete with anti-individualistic medieval survivors, among them a tendency not to enforce executory contracts where there was no part performance by the promisee." ${ }^{53}$ Metzger also lists a number of categories within which gratuitous promises were enforced by the courts even during the heyday of classical contract law theory due to detrimental reliance. ${ }^{54}$ Similarly, Sutton accounts for several English doctrines which enforce promises "which have not been bargained for but on which the promisee has justifiably relied to his detriment," ${ }^{155}$ including: proprietary estoppel, ${ }^{56}$ estoppel by representation, ${ }^{57}$ waiver, ${ }^{58}$ promissory estoppel, ${ }^{59}$ and breach of warranty of authority. ${ }^{60}$ Furthermore, as noted by Collins, the absence of a developed reliance model in classical contract law did not mean, therefore, that reliance was never protected: it simply "led to the practice of the courts becoming ever more ingenious in discovering implied requests to perform actions, in order to bring a deserving case within the exchange model of consideration. ${ }^{.61}$

See J.B. Milner's discussion of this point in "The Law of Contract: 1923-1947" (1948) 26 Can. Bar Rev. 117 at 123-24.

Farnsworth, supra note 27 at 90, quoting Holmes from Commonwealth v. Scituate Sav. Bank, 137 Mass. 301 at 302 (1884).

Metzger, supra note 18 at 482.

Ibid. at 482 ff. For a Canadian example of this, see Wright's reference to Hubbs v. Black in "Contracts-Charitable Subscriptions-Consideration," supra note 13 at 111, n. 18 wherein "an unrequested expenditure of money was held to 'make the consideration perfect even if otherwise defective."

Supra note 31 at 44.

Ibid. at 61 . Gilmore, supra note 22 at 64 , suggests that 'estoppel' is "simply a way of saying that, for reasons which the court does not care to discuss, there must be judgment for the plaintiff."

Supra note 31 at $44 \mathrm{ff}$.

Ibid. at $78 \mathrm{ff}$.

Ibid. at $49 \mathrm{ff}$.

Ibid. at $76 \mathrm{ff}$.

Supra note 18 at 73. 
Though its roots go back into history, the reliance model gathered considerable momentum by midway through the twentieth century. As conceptualized by Collins, based in part on the decision of Crabb v. Arun District Council, ${ }^{62}$ the model enforces promises unsupported by consideration provided that there is: deliberate encouragement by the person making a representation; detrimental reliance by representee; reasonable reliance by representee; and an unconscionable result if the representor were allowed to resile. ${ }^{63}$ Under such context-based circumstances, reliance does "generate obligations to transfer property, to refrain from certain courses of action, and to compensate others for their frustrated expectations during commercial dealings. ${ }^{164}$

Though theorists appear to be reluctant to identify when in the twentieth-century the reliance model gained its renewed foothold, ${ }^{65}$ there is no doubt that the model was dramatically revitalized by Lord Denning in his 1947 decision of High Trees ${ }^{66}$ in which it was held that representations going to the future were enforceable even absent consideration. As Metzger states:

Promissory estoppel clearly displays many of the traits ... identified as characterizing contemporary contract law. First, the doctrine's prevalence obviously evidences the movement away from formalism.... Secondly, the rise of promissory estoppel exhibits classical contract law's diminished influence in the twentieth century.... Finally, we need not elaborate on the ways promissory estoppel has expanded the range of situations where contract liability occurs. In its role as substitute for missing contractual elements, it clearly increases the chance that the promisor will have to answer for his promise. ${ }^{67}$

More will be said on High Trees later in this article.

Values and objectives propelling the reliance model are those of fairness, equity, the protection of reasonable commercial expectations, the prevention of abuses of trust, ${ }^{68}$ and even communitarianism: ${ }^{69}$

Instead of envisioning society as a collection of antagonistic individuals trading exclusively in the light of self-interest, the modern law recognizes the need to protect individuals who co-operate in relations

[1976] Ch. 179.

Supra note 18 at $68 \mathrm{ff}$.

Jbid. at 77.

For example, according to Farnsworth, supra note 27 at 89 , it was not until the twentieth century that a generalized theory of recovery based on reliance developed. He is not more specific than this.

Supra note 17.

Metzger, supra note 18 at 504-505.

Collins, supra note 18 at 87.

Ibid. While it is impossible to give a definitive account of what communitarianism means, it does involve the claim that "we are partly defined by the communities we inhabit ...[and] we must also be implicated in the purposes and ends characteristic of those communities." See M. Sandel, ed., Liberalism and its Critics (Oxford: Basil Blackwell, 1984) at 6. See also S. Mulhall \& A. Swit, Liberals and Communitarians (Oxford: Basil Blackwell, 1992) at 294 who, inter alia, note that: against, the liberal's emphasis upon autonomy, the communitarian sets an emphasis upon dependence; against the liberal claim that my life is my own to make of what I will, the communitarian sets the claim that the loci of value in my life are often to be found outside myself. 
of economic interdependence and trust.... Inevitably, this more communitarian vision leads to a reduction in the scope of individual liberty, in the sense of freedom from unwanted obligations, by clouding the hard lines drawn by classical law between binding exchange relations and uninhibited freedom of action. ${ }^{70}$

Based on the foregoing analysis, the consideration and reliance-based theories of contractual liability can be summarized in the following way:

\begin{tabular}{|c|c|c|c|}
\hline $\begin{array}{l}\text { TEST OF } \\
\text { ENFORCEABILITY }\end{array}$ & Rationale & Values & HEYDaY \\
\hline $\begin{array}{l}\text { Promisor has received } \\
\text { consideration. }\end{array}$ & $\begin{array}{l}\text { BARGAIN THEORY OF } \\
\text { CONTRACT: the } \\
\text { promise is enforced } \\
\text { because it has been } \\
\text { paid for. } \\
\text { WILL THEORY OF } \\
\text { CONTRACT: the } \\
\text { promise is enforced } \\
\text { because the parties } \\
\text { have agreed to be } \\
\text { bound. }\end{array}$ & $\begin{array}{l}\text { Laissez faire } \\
\text { economic liberal } \\
\text { values of } \\
\text { individualism, } \\
\text { consensualism, and } \\
\text { freedom of contract. }\end{array}$ & $\begin{array}{l}\text { Nineteenth } \\
\text { century. }\end{array}$ \\
\hline $\begin{array}{l}\text { Promisor has induced } \\
\text { reliance by the } \\
\text { promisee. }\end{array}$ & $\begin{array}{l}\text { RELIANCE-BASED } \\
\text { LIABILITY: the promise } \\
\text { is enforced because } \\
\text { the promisor intended } \\
\text { for it to be relied upon } \\
\text { and it was relied } \\
\text { upon. }\end{array}$ & $\begin{array}{l}\text { Fairness, equity, } \\
\text { conscience, } \\
\text { commercial } \\
\text { expectations, } \\
\text { communitarianism. }\end{array}$ & Twentieth century. ${ }^{72}$ \\
\hline
\end{tabular}

\section{MODERN EXAMPLES OF RELIANCE-BASED LIABILITY}

Several modern contract law doctrines specifically bear out the assessment that the law also enforces promises on the basis of reliance and reasonable expectations. In this section, I will briefly review some examples of this newer phenomenon, which admittedly had a modest presence even in the days of assumpsit. ${ }^{73}$

Collins, ibid. at 87.

Cooke, supra note 18 at 17 observes that there are two schools of thought regarding the development of a general theory of contract and that the:

difficulty for any researcher looking for ideological shifts, is that there was very little law of contract in the modern sense before the nineteenth century.... What is clear is that a general theory of contract did emerge in the nineteenth century.

As Sutton notes in "Promises and Consideration" in Finn, supra note 21 at 45, the bargain theory of consideration which saw renewed stability in the nineteenth century has, in the twentieth century, seen a gradual erosion "with belated recognition of the fact that there are other bases on which the enforceability of promise may rest...."

Farnsworth, supra note 27 at 90 .

Ibid. at 89. 


\section{A. PROMISSORY ESTOPPEL}

In 1947, the doctrine of promissory estoppel became reestablished, thereby signalling the largest development in contract law since the first year of the Law School's operation. The doctrine, catapulted into prominence by Lord Denning in Central London Property Trust Ltd. v. High Trees House Ltd. ${ }^{74}$ sought to compensate for the limited scope of estoppel by representation ${ }^{75}$ by extending the enforceability of certain promises which are otherwise unsupported by consideration. Until High Trees, promisees seeking to rely on non-contractual representations going to the future were generally met by the principle stated in Jorden v. Money ${ }^{76}$ and summarized by Lord Denning in the following way: "a representation as to the future must be embodied as a contract or be nothing." ${ }^{\text {"77 }}$ Lord Denning, however, "breathed new life" ${ }^{178}$ into the doctrine of promissory estoppel by configuring certain precedents to stand for the following proposition:

[These] are cases in which a promise was made which was intended to create legal relations and which, to the knowledge of the person making the promise, was going to be acted on by the person to whom it was made, and which was in fact so acted on. ${ }^{79}$

The fundamental principle, as emphasized subsequently by the House of Lords in The Post Chaser, ${ }^{80}$ is contained in the 1877 Hughes decision, namely that "the representor will not be allowed to enforce his rights 'where it would be inequitable having regard to the dealings which have taken place between the parties.' ${ }^{\text {"BI }}$ Reasonable reliance by the promisee is thereby a key trigger for establishing the defence of promissory estoppel.

Promissory estoppel, now a staple of contract law, was expressly recognized as part of Canadian law by the Supreme Court of Canada in Conwest Exploration Co. v. Letain $^{82}$ and in numerous cases since then. ${ }^{83}$ The most recent, classical articulation

Supra note 17. This doctrine is ostensibly based on earlier decisions such as Hughes v. Metropolitan Ry. Co. (1877), 2 App. Cas. 439 at 134 (H.L.), Denning L.J.

See G.H. Treitel, The Law of Contract, 8th ed. (London: Sweet \& Maxwell, 1991) at 361:

Under the doctrine of estoppel by representation, a person who makes precise and unambiguous representation of fact may be prevented from denying the truth of the statement if the person to whom it was made was intended to act on it and did act on it to his detriment [emphasis added, footnotes deleted].

As a result, estoppel by representation does not enforce representations going to the future. (1854), 10 E.R. 868 (H.L.).

High Trees, supra note 17 at 134.

Société Italo-Belge pour le Commerce (The Post Chaser), [1982] 1 All E.R. 19 at 27 (Q.B.).

Supra note 17 at 134.

Supra note 78.

Ibid. at 26, quoting with approval Hughes v. Metropolitan Ry Co., supra note 74, which, in turn, is recognized by Denning in High Trees, supra note 17, as an earlier formulation of the doctrine of promissory estoppel.

[1964] S.C.R. 20 at 28 where Mr. Justice Judson notes that "it does not seem to me that the recent interest in England in this subject-matter, beginning with ... High Trees ... has done anything more than to restate the principle [in Pierce v. Emprey, [1939] S.C.R. 247]." 
of the doctrine by Canada's highest court is found in Maracle v. Travellers Indemnity Co. of Canada:

The principles of promissory estoppel are well settled. The party relying on the doctrine must establish that the other party has, by words or conduct, made a promise or assurance which was intended to affect their legal relationship and to be acted on. Furthermore, the representee must establish that, in reliance on the representation, he acted on it or in some way changed his position.

Thus stated, the doctrine requires, inter alia, that the parties be in a preexisting legal relationship and that, concomitantly, the doctrine be used defensively as a shield, not as a sword to found a cause of action. ${ }^{85}$

Significantly, the New Brunswick Court of Appeal has cut back on this limitation on the doctrine's operation in the 1990 decision of Robichaud v. Caisse Populaire. ${ }^{86}$ Here, the court allowed the plaintiff to use promissory estoppel to found a cause of action against the Caisse when it tried to renege on an agreement to accept a lesser sum of money in full satisfaction of a larger debt. As the court stated:

If the principle of promissory estoppel could be invoked successfully as grounds of defence in an action by the Caisse Populaire against the appellant, then, considering the relations between them, to refuse its application on the pretext that it is not invoked as grounds of defence is, in my opinion, untenable and contrary to the principles of equity on which the doctrine is based. In the case at bar, the appellant is merely asking that the Caisse Populaire respect the promise that it made to him and which he relied to his detriment. ${ }^{87}$

This approach is daring - though arguably consistent with the equitable foundation of the doctrine - for at least two reasons. First, because New Brunswick does not have Judicature Act legislation which enforces a promise to pay a lesser sum even absent consideration, the court is flatly contradicting the rule in Foakes v. Beer ${ }^{88}$ Second, there is an absence of precedent supporting the proposition that promissory estoppel can

For a useful account of leading Canadian cases, see G.H.L. Fridman, The Law of Contract, 3d ed. (Scarborough: Carswell, 1994) at 121-36. (1991), 80 D.L.R. (4th) 652 at 656. The Alberta Court of Appeal in First City Trust v. Triple Five Corp., [1989] 3 W.W.R. 577, leave denied [1990] 1 W.W.R. Ixxi, has recently considered the doctrine of promissory estoppel, and follows other classic articulations of the doctrine as stated in cases such as John Burrows v. Subsurface Surveys Lid. (1968), 68 D.L.R. (2d) 354 (S.C.C.) and Engineered Homes v. Mason (1983), 146 D.L.R. (3d) 577 (S.C.C.). See also Smoky River Coal Limited v. United Steelworkers of America (1985), 38 Alta. L.R. (2d) 193 (C.A.) and Saskatchewan River Bungalows Ltd. v. Maritime Life Assurance Co. (1992), 92 D.L.R. (4th) 372 (Alta. C.A.), rev'd on other grounds (1994), 115 D.L.R. (4th) 478. It should be noted that the Supreme Court of Canada in Saskatchewan River Bungalows Ltd. does not expressly consider the doctrine of promissory estoppel confining its analysis to waiver. The court did note that "waiver and promissory estoppel are closely related," and stated that, for the purposes of the appeal, "it was not necessary to determine how or whether the two doctrines should be distinguished": ibid. at 483 . 
be used as a sword and the existence of considerable authority to the contrary. As Lord Denning stated in Combe v. Combe: promissory estoppel "may be part of a cause of action, but not a cause of action in itself." ${ }^{\prime 89}$ Numerous cases have reaffirmed this limitation on the defense, though it has been criticized elsewhere. ${ }^{90}$

In Alberta, the case of Deer Valley Shopping Centre Ltd. v. Sniderman Radio Sales and Services appeared to make the claim that promissory estoppel can be used as a sword:

It has been suggested that estoppel can only be used as a shield, not as a sword. Thus estoppel cannot be used to enforce the promises made, but only as a defence where the promisor attempts to go back in his promise and enforce his rights as they stood before the representation. However, in my view, this is not the present state of law. ${ }^{\text {1 }}$

On the facts of the case, this broader claim was not necessary. In Deer Valley, the landlord-plaintiff sued the tenant on the lease and was met by a defence regarding a defect in notice given to the tenant by the landlord. As the tenant had earlier represented to the landlord that it would not rely on this defect, the landlord raised an estoppel to counter the tenant's defence, as opposed to using it to found a cause of action. ${ }^{92}$ The former is entirely permissible based on existing authority such as Charles Rickards Ltd. v. Oppenhaim. ${ }^{93}$ The latter is not. ${ }^{94}$

The requirement for a preexisting legal relationship - heretofore a fixture of promissory estoppel - has been expressly disregarded by the Australian High Court in Waltons Stores (Interstate) Pty. Ltd. v. Maher, where the court emphasized that the real grounding of promissory estoppel focused on unconscionability ${ }^{95}$ and that:

[T] he principle that equity will come to the relief of a plaintiff who has acted to his detriment on the basis of a basic assumption in relation to which the other party to the transaction has 'played such a

89 Combe, supra note 85 at 220.

90 Cases following Combe include: Canadian Superior Oil Lid. v. Paddon-Hughes Dev. Co. (1970), 12 D.L.R. (3d) 247 at 251 (S.C.C.); Gilbert Steel Ltd. v. University Const. Ltd. (1976), 67 D.L.R. (3d) 606 at 610 (Ont. C.A.); and more recently, Watson Estate v. Canada Mortgage and Housing Corp., [1995] A.J. No. 181 (Alta Q.B.) (QL) and Reclamation Systems Inv. v. The Honourable Bob Rae (1996), 27 O.R. (3d) 419 (Ont. Ct. (Gen. Div.)). Criticisms are found in Edwards v. HarrisIntertype (Canada) Ltd.(1983), 40 O.R. (2d) 558 (H.C.J.) and other cases cited by Fridman, supra note 83 at 125 , n. 266-72 and accompanying text.

91 (1989), 96 A.R. 321 (Q.B.) at 333 [hereinafter Deer Valley].

92 That is, the landlord was suing on the lease, not on the representation made the tenants regarding the allegedly defective notice.

93 [1950] 1 K.B. 616 (C.A.).

94 In Gilbert Steel Lid., supra note 90, a supplier sued on the purchaser's promise to pay an additional sum for steel which the supplier had formerly contracted to provide at a lower price. This, according to Wilson J.A. (as she then was) amounted to using promissory estoppel to found a cause of action, which was impermissible. 
part in the adoption of the assumption that it would be unfair or unjust if he were left free to ignore it."\%

The court thereby recognized that promissory estoppel can operate in the context of a pre-contractual relationship.

Given the unusual facts of the case, this finding was critical to the plaintiff being able to rely on promissory estoppel. Waltons, the prospective tenant, had been negotiating with Maher, the prospective landlord, for a lease. The concept was that the existing building on the site would be demolished and the landlord would put up a new building, according to the tenant's specifications. There was urgency surrounding the negotiations, at the behest of the prospective tenant. On November 7, 1983, Maher informed the solicitors for the prospective tenant that an agreement would have to be concluded "within the next day or two" in order to meet the tenant's time lines. In reply, Waltons' solicitors sent over a draft lease, stating that they would notify Maher the next day if his proposed amendments were not agreed to by their client. Within four days, Maher executed the lease and heard nothing more from Waltons until, by letter dated January 19, 1984, Waltons' solicitors informed Maher that their client "did not intend to proceed" 97 and returned the lease unexecuted. By this time, however, Maher had demolished a portion of the old building and begun construction of the new one, to the knowledge of Waltons as early as December 10, 1983.

The court could not make a finding that Maher "actually believed that contracts had been exchanged or that a binding contract had come into existence" 98 and hence, one of the historical ingredients to the defence of promissory estoppel was missing. Common law estoppel could not be invoked because any representation by the prospective tenant that the exchange of contracts would take place was a representation going to the future..$^{99} \mathrm{~A}$ remedy in restitution would be difficult to establish because while Maher suffered a detriment (by demolishing a building and erecting a new one), there was no corresponding benefit accruing to Waltons. And finally, trying to establish an obligation on the prospective tenant to compensate based on the doctrine of mistaken improvements to land would be problematic because Maher made improvements to his own land, not to another's. ${ }^{100}$

It was in the context of this dilemma that the court took due note of English and Australian authorities which would prevent a finding a promissory estoppel as well as of the American Restatement on Contract, 2d par. 90 which would permit the court to do so. The Restatement provides:

Ibid. quoting Dixon J. in Grundt.

Ibid. at 517.

Ibid at 518.

Ibid. at 519.

As Treitel notes, supra note 75 at 124: "Proprietary estoppel is said to arise in certain situations in which a person has done acts in reliance on the belief that he has, or will acquire, rights in or over another's land.... Where the requirements of proprietary estoppel are satisfied, the landowner is precluded from denying the existence of the rights in question, and may indeed be compelled to grant them." 
(1) A promise which the promisor should reasonably expect to induce action or forbearance on the part of the promisee or a third person and which does induce such action or forbearance is binding if injustice can be avoided only by enforcement of the promise. The remedy granted for breach may be limited as justice requires. ${ }^{101}$

After noting that developments regarding the doctrine in the United States should be regarded "with some caution,"102 the court followed the American lead and allowed Maher to rely on Waltons' representation because:

[P]romissory estoppel indicates that the doctrine extends to the enforcement of voluntary promises on the footing that a departure from the basic assumptions underlying the transaction between the parties must be unconscionable. As failure to fulfil a promise does not of itself amount to unconscionable conduct, mere reliance on an executory promise to do something, resulting in the promisee changing his position or suffering detriment, does not bring promissory estoppel into play. Something more would be required ... [namely] in the creation or encouragement by the party estopped in the other party of an assumption that a contract will come into existence...." ${ }^{103}$

The court went on to criticize Waltons' inaction in light of all the circumstances:

It was unconscionable for ... [Waltons], knowing that ... [Maher] were exposing themselves to detriment by acting on the basis of a false assumption, to adopt a course of inaction which encouraged them in the course they had adopted. To express the point in the language of promissory estoppel the appellant is estopped in all the circumstances from retreating from its implied promise to complete the contract. $^{104}$

Does Maher thereby signal the end of formal requirements surrounding the doctrine of promissory estoppel? This would seem not to be the case. As Mark Dorney notes in the Australian context:

The new equitable estoppel is a carefully confined doctrine which is in no way an invitation to openended discretion in the enforcement of ... [promises]. Rather, Waltons, introduced a new unity to the several manifestations of equitable estoppel, a unity based on equity's ancient bogeyman, 'unconscionable conduct'.... More especially, cases like Austotel [(1989) 16 NSWLR 582] have introduced a further limitation of estoppel to promises accompanied by the requisite legal intention. It is in the confines of the definition of unconscionability, and in this intention, that the first signs of an attempt to mark out the bounds of the new doctrine can be found. ${ }^{\text {los }}$

It is difficult to predict whether Canadian courts will follow the Australian lead, particularly as Waltons has only thus far been referred to in one case. ${ }^{106}$ Part of the issue will be whether the Australian approach is consistent not just with the American

Waltons, supra note 39 at 522.

Ibid.

Ibid. at 525.

Ibid. at 526.

M. Dorney, "The New Estoppel" (1991) 7 Australian Bar Review 19 at 46.

Welch v. O'Brian Financial Corp. (1991), 86 D.L.R. (4th) 155 (B.C.C.A.). A Q.L search conducted on June 20, 1996 indicates that no other case has considered Waltons. 
view of estoppel but also with the Anglo-Canadian view. It has been observed that the American conception of promissory estoppel is intrinsically broader than the common law articulations in England and Canada would admit and that the American doctrine of consideration is arguably stricter. ${ }^{107}$ The court in Waltons notes, however, that in both the United States and Australia (and, presumably, in England and Canada): "there is an obvious interrelationship between the doctrines of consideration and promissory estoppel, promissory estoppel tending to occupy ground left vacant due to the constraints affecting consideration." ${ }^{108}$ Further, the court ties the American account of promissory estoppel to larger notions of unconscionability, notions which are, of course, well recognized in the English, Australian, and Canadian context as well. Indeed, the court relies on the English precedent of Crabbe v. Arun District Council to link promissory estoppel to notions of unconscionability. ${ }^{109}$ As the court states, Crabbe, a case of proprietary estoppel,

lends assistance to the view that promissory estoppel may in some circumstances extend to the enforcement of a right not previously in existence where the defendant has encouraged in the plaintiff the belief that it will be granted and has acquiesced in action taken by the plaintiff in that belief. ${ }^{.10}$

English commentary on Waltons, while not extensive, has been favourable. Adam Duthie, for example, praises the majority judgments for providing "valuable insight into the workings of the doctrine of equitable estoppel" ${ }^{\prime \prime \prime}$ and notes a similar trend in England to assimilate the historically distinct doctrines of promissory estoppel and proprietary estoppel as "facets of a more general equitable jurisdiction to relieve against unconscionable conduct," 112 though English courts still do require a preexisting contractual relationship to found the defense of promissory estoppel. In the context of the Waltons case, Duthie states that:

[E]quity's predominant concern with unconscionability and detrimental reliance would seem to require that this limitation [of a preexisting legal relationship] be dispensed with, since in a particular case denial of a future right may be just as reprehensible as insistence upon an existing right. ${ }^{133}$

And given the specific prerequisites to invoking the Australian doctrine, Duthie does not share the concern of those who worry that removing this existing precontractual relationship requirement could become the "talisman for the idiosyncratic effectuation of promises and expectations." ${ }^{\text {114 }}$

Supra note 39 at 522: The court observes that the English tradition may be more "willing to imply consideration in situations where the bargain theory as implemented in the United States would deny the existence of consideration."

lbid.

Ibid. at 523.

Ibid.

A. Duthic, "Equitable Estoppel, Unconscionability and the Enforcement of Promises" (1988) 104 Law Quarterly Review 362 at 366.

Ibid. at 362. J. Kidd comments on the same trend in "Promissory Estoppel in Australian Contract Law: The Significance of the Walton Stores Decision" (1990) Feb. Business Law Review 52. Duthie, ibid. at 366.

Ibid. at 362, quoting P.D. Finn, ed., Essays in Equity (North Ryde: Law Book Co., 1985) 74-75. 
Similarly, John Kidd asserts that the Australian court's decision to abandon "illogical restraints on the doctrine" has better enabled it to relieve against unconscionable conduct, ${ }^{115}$ albeit in exceptional situations. He too observes a tendency in some English judges to bring promissory estoppel and proprietary estoppel together as an overall principle of equitable estoppel, though not, of course, to the extent that this has occurred in Australian law. ${ }^{116}$ Furthermore, he notes that the Privy Council has already "left open the faint possibility 'in circumstances at present unforeseeable' of the estoppel requirements being fulfilled despite a 'subject to contract' clause," that is, when the parties are still in a pre-contractual relationship. ${ }^{117}$

It can be observed that, even its classical formulation requiring a preexisting legal relationship, promissory estoppel represents a freestanding, alternate ground for enforcing a gratuitous promise the rationale for which is now largely uncontroversial: the judicial wish to enforce the reasonable expectations of the promisee and to discourage unconscionable or unfair behaviour in the promisor. As a doctrine which possesses a communitarian overlay, it reduces the scope of individual freedom in the marketplace and demands that a measure of commercial morality be respected. Nonetheless, it merely coexists with consideration as a basis for liability and does not function to obliterate the doctrine of consideration because, as Lord Denning states in Combe: "The doctrine of consideration is too firmly fixed to be overthrown by a sidewind."118

Further, even in its expanded Australian-American manifestation, the doctrine cannot overtake consideration. As Kidd notes:

[E]nforcement of a non-contractual promise is conditional on the promisor's reasonable expectation that his promise will induce action or forbearance by the promisee, and the mere fact that a promisee has acted to his detriment in reliance on a gratuitous promise does not make it unconscionable for the promisor to fairly abide by it so as to attract estoppel. As stated by Goff J. in the Texas Bank case ... in the usual case of a gratuitous promise ... 'the promisee may be reasonably expected to appreciate that, to render it binding, [it] must be incorporated in a binding contract or contractual variation." 119

\section{B. THE THIRD PARTY BENEFICIARY}

Another area which signals the trend toward enforceability of bare promises concerns the rights of third party beneficiaries to a contract. Though early case law indicated that "the party to whom the benefit of a promise accrews" could sue on the promise though not a party, ${ }^{120}$ the 1861 decision of Tweddle v. Atkinson reversed this rule. ${ }^{121}$ As

Supra note 112 at 54.

lbid.

Ibid. at 53, ref. to Altorney-General of Hong Kong v. Humphreys Estate, [1987] 1 A.C. 114 (H.L.).

Combe, supra note 85 at 220.

Kidd, supra note 112 at 54 .

Provender v. Wood (1860), Het. 30, 124 E.R. 318. See also Dutton v. Poole (1678), 2 Lev. 210, 83 E.R. 523. For a comprehensive discussion of the doctrine of privity, see R. Flannigan, "Privity - The End of An Era (Error)" (1987) 103 L.Q.R. 564.

Supra note 5. 
Crompton J. asserts in Tweddle, the "modern cases have, in effect, overruled the old decisions; they show that the consideration must move from the party entitled to sue upon the contract." ${ }^{122}$ With rare exceptions, ${ }^{123}$ this privity rule was strictly enforced.

The law, of course, established limited routes around the privity rule, including the finding that a trust exists so that the third party - cast as a beneficiary - can sue, ${ }^{124}$ through the construction of a collateral contract, ${ }^{125}$ and through agency. ${ }^{126}$ The lastmentioned technique is given its classic articulation in New Zealand Shipping Co. Ltd. v. A.M. Satterthwaite ${ }^{127}$ through which stevedores were able to take the benefit of an exemption clause contained in a bill of lading to which they were not clearly parties. ${ }^{128}$ Through the doctrine of agency, the court determined that consignee and stevedores were in fact contracting with each other through the agency of the shipper; accordingly, the problem of privity did not arise. It is true that application of the doctrine of agency on these facts required the court to engage in some finessing, as observed by Viscount Dilhorne in dissent, ${ }^{129}$ but did accomplish the equitable outcome of giving effect to the parties' intentions at the time of contracting which were that the stevedores would be accorded effective protection from liability.

It is this sense of fairness and desire to enforce the parties' expectations that propelled the Supreme Court of Canada to create an express exception to the doctrine of privity in the 1992 case of London Drugs Ltd. v. Kuehne \& Nagle International. ${ }^{130}$ In that case, London Drugs delivered a transformer to Kuehne for storage pursuant to the terms of a standard form contract. A clause in this contract purported to limit the

Ibid. at 398.

Elder, Dempster \& Co. v. Paterson Zochonis \& Co., [1924] A.C. 522 This case is frequently regarded as per incuriam. See also Lord Denning's analysis in Beswick v. Beswick, [1966] $1 \mathrm{Ch}$. 538, [1966] 3 All E.R. 1 at 5 (C.A.), aff'd on other grounds [1968] A.C. 58, [1967] 2 All E.R. 1197 , in which the problem of a third party beneficiary seeking to enforce a contract is recast by his Lordship as resolvable through proper pleadings:

We have here the standard pattern of a contract for the benefit of a third person. A man has a business or other assets. He transfers them to another and, instead of taking cash, takes a promise by that other that he will pay an annuity or other sum to his widow or children. Can the transferee take the assets and reject the promise? I think not. In my opinion, a contract such as this, for the benefit of widow and children, is binding.... The widow and children can join with the executor as plaintiffs in the action. If he refuses to sue, they may sue in their own names joining him as a defendant. In this way they have a right which can be enforced....

See also Flannigan's analysis, supra note 120 at $572 \mathrm{ff}$.

Greenwood Shopping Plaza v. Beattie (1980), 111 D.L.R. (3d) 257 (S.C.C.) [hereinafter Greenwood].

Clarke v. Dunraven; The Satanita, [1897] A.C. 59 (H.L.). See also Re Spike and Rocca Group Ltd. (1979), 107 D.L.R. (3d) 62 (P.E.I.S.C.) where the court relied on a "community of interest" between individual tenants in a shopping centre so as to create "an indirect privity of contract": ibid. at 68.

Greenwood, supra note 124.

[1975] A.C. 154 at $167-68$ (P.C.).

The agency "exception" to the doctrine of privity has been followed in other cases including McCannell v. Mabee McLaren Motors Ltd., [1926] 1 W.W.R. 353 (B.C.C.A.). 
liability of the "warehouseman" for loss to $\$ 40.00$. When loss occurred due to the negligence of two employees of Kuehne, London Drugs sued those employees for the full amount of the loss on the theory that the protection of the clause did not extend to them. Mr. Justice lacobucci, for the majority, stated London Drugs' analysis was correct on the strict theory of privity but that:

I believe that this Court is presented with an appropriate factual opportunity in which to reconsider the scope of this doctrine and decide whether its application in cases such as the one at bar should be limited or modified. It is my opinion that commercial reality and common sense require that it should. ${ }^{131}$

\section{His Lordship then goes on to state the following test:}

I am of the view that employees may obtain ... [the benefit of the limitation of liability clause] if the following requirements are satisfied:

(1) The limitation of liability clause must, either expressly or impliedly, extend its benefit to the employees (or employee) seeking to rely on it; and

(2) the employees (or employee) seeking the benefit of the limitation of liability clause must have been acting in the course of their employment and must have been performing the very services provided for in the contract between their employer and the plaintiff (customer) when the loss occurred. ${ }^{132}$

Iacobucci J. emphasized that his change to the doctrine of privity is "incremental," ${ }^{133}$ "very specific"134 and that he was only recognizing "a limited jus tertii."135 The Supreme Court has subsequently confirmed the restricted scope of lacobucci J.'s exception to the doctrine, noting that for a limitation of liability clause to cover those seeking its protection, it must be established that the exemption was intended to cover them. ${ }^{136}$

Though the decision has been subject to some criticism, ${ }^{137}$ S.M. Waddams is correct to welcome it for restoring "flexibility to an area of contract law much in need

Ibid. at 414-15.

Ibid at 448. While he did not identify it as an element in the test for when employees might obtain the protection of a limitation of liability clause, Mr. Justice lacobucci did underscore in his reasons that additional insurance was readily available to London Drugs had it chosen to take advantage of such an opportunity. In this way, his Lordship emphasized that the parties had consciously allocated risk of loss by virtue of the liability clause in question and intended that it would cover the employees of the warehouseman.

Ibid. at 449.

Ibid. at 450.

Ibid. Note that McLachlin J. delivered a concurring opinion which focussed on the tort doctrine of voluntary assumption of risk. La Forest J., in a concurring opinion, held that the employees owed no duty to the plaintiff.

Edgeworth Construction Ltd. v. N.D. Lea \& Associates Lid., [1993] 3 S.C.R. 206.

See M. Baer, "Contracts-Third Party Beneficiaries" (1993), 72 Can. Bar Rev. 385 and N. Siebrasse, "Third-Party Beneficiaires in the Supreme Court: Categorization and the Interpretation of Ambiguous Contracts" (1995) 45 University of Toronto Law Journal 47. 
of it."138 Indeed, absent Iacobucci J.'s modification of the doctrine, the appellant would have unjustly circumvented a "limitation of liability clause to which it had expressly consented."139

London Drugs has been applied by several courts including the Ontario Court, General Division in M.A.N - B \& W Diesel v. Kingsway Transports Ltd., ${ }^{140}$ and the Alberta Court of Queen's Bench in Anchor Fence Inc. v. Polaris Realty Corp ${ }^{141}$ as well as having been considered by a score of others. ${ }^{142}$ It is referenced here as another example of how the law of contracts continues its movement toward enforcing promises without the requirement of privity or consideration moving from the promisee.

\section{VULNERABLE PRECEDENTS}

That the latter half of the twentieth century has witnessed an expansion of reliancebased liability leads one to question the stability of such precedents as Dickinson v. Dodds, which, for example, holds that even offers expressed to be irrevocable for a fixed period of time can be revoked prior to then. ${ }^{143}$ As it is, the unsatisfactory quality of the precedent, in the context of reasonable reliance by the promisee, has meant that while the courts may pay lip-service to the rule, "they have ignored the rule in cases where it would be unfair not to."144

Certainly, this appears to account, in part at least, for the Supreme Court of Canada's ruling in $R$. v. Ron Engineering ${ }^{145}$ wherein it was held that a tender offer, expressed to be irrevocable, could not be withdrawn even prior to acceptance. As noted by David Percy, Ron Engineering thereby signals a break with the previously accepted proposition that "the contractor is free to withdraw the tender and is owed no obligation by the owner under ordinary circumstances." 146

"Privity of Contract in the Supreme Court of Canada" (1993) 109 L.Q.R. 349 at 352.

London Drugs, supra note 130.

(1993), 15 O.R. (3d) 106.

Anchor Fence Inc. v. Polaris Realty Corp. (1994), 156 A.R. 81 (Q.B. in Chambers).

See e.g. the Ontario Court of Appeal in Wolverine Tube (Canada) Inc. v. Noranda Metal Industries Lid. (1995), 26 O.R. (3d) 577; and the British Columbia Court of Appeal in British Columbia v. R.B.O. Architecture Inc., [1995] 6 W.W.R 679 (B.C.S.C.) and Froese v. Montreal Trust Co., [1996] B.C.J. No. 1091 (C.A.)(Q.L.).

Supra note 3.

"Contracts and the Protection of Reasonable Expectations" in Reiter \& Swan, supra note 26 at 43. As an example, the authors cite Dawson v. Helicopter Exploration Ltd., [1955] S.C.R. 868 wherein the court determined that, where possible, it should hold offers that might be considered unilateral as, in fact, calling for bilateral action. As Reiter and Swan, ibid. at 44, conclude: "What has happened here is that the power of the offeror to revoke at any time before acceptance has been destroyed by the simple expedient of finding that there was a bilateral contract."

(1981), 119 D.L.R. (3d) 267 (S.C.C.).

D. Percy, "Radical Developments in the Law of Tenders: A Canadian Reformulation of Common Law Principles" (1988) 4 Construction Law Journal 171. 
According to Estey J., the tenderer could not withdraw its tender because its promise of irrevocability for sixty days was supported by consideration and thereby contractual. This initial contract is identified by his Lordship as:

[C]ontract ' $A$ ' to distinguish it from the construction contract itself, which would arise on the acceptance of the tender, and which I refer to as Contract 'B.' Other terms and conditions of this unilateral contract which arose by the filing of a tender in response to the call therefor under the aforementioned terms and conditions, included the right to recover the tender deposit 60 days after the opening of tenders if the tender was not accepted by the owner. This contract is brought into being automatically upon the submission of a tender. ${ }^{147}$

Though it relies on flawed analysis, ${ }^{148}$ Ron Engineering has "assumed the status of settled law"149 and demonstrates the court's determination to work around the doctrine of consideration as required. As Percy comments:

[t] he court's explanation that consideration can be found in the 'qualified obligation of the owner to accept the lowest tender' is specious. In most cases there is no obligation to accept the lowest or any tender, as a result either of an express term to that effect or of the application of the ordinary law of contracts. If this is the case, the only real benefit received by the contractor is the implied promise that the owner will consider its tender, but such a promise has generally been held not to amount to consideration.... [I]f an implied agreement to consider the offer amounts to consideration, then virtually every offer that is expressed to be irrevocable for a certain period would be binding. ${ }^{150}$

Given trends, it may be that-particularly where there is reasonable reliance by the promisee on a firm offer outside the tendering context - the Canadian courts will be inclined to follow the Australian lead in Waltons ${ }^{151}$ or expand the reach of Ron Engineering to make the firm offer binding.

For similar reasons, the rule in Gilbert Steel ${ }^{152}$ that contractual variations must be supported by consideration may also be less than secure. Indeed, the English Court of Appeal in Williams v. Roffey Bros. ${ }^{153}$ has broken with precedent and recently determined that the fulfilment of a preexisting contractual obligation can be good consideration supporting a fresh promise from the other party to the agreement. ${ }^{154}$

Supra note 145 at 272 . It should be noted that the contractor's claim was denied on the basis of the law of mistake, according to the court.

148 For accounts of the limitations in the court's analysis, see Percy, supra note 146; and R. Nozick, "Note" (1982) 60 Can. Bar Rev. 345; and G.H.L. Fridman, "Tendering Problems" (1986) 66 Can. Bar Rev. 582.

149 Percy, ibid. at 174.

iso Ibid.

151 Supra note 39.

192 Supra note 90 . It should be noted that this case has itself been subject to considerable criticism, including J. Reiter, "Courts, Consideration and Common Sense" (1977) 27 U. of T.L.J. 439.

133 [1990] I All E.R. 512 (C.A.) [hereinafter Roffey].

154 Most notably, this decision is at odds with Stilk v. Myrick (1809), 2 Camp. 317, but, as the court emphasized, only incrementally. In the words of Russell L.J., ibid. at 524:

In the late twentieth century I do not believe that the rigid approach to the concept of consideration to be found in Stilk v. Myrick is either necessary or desirable. Consideration 
The facts of Roffey are these: Roffey was a contractor who had subcontracted with Williams to do some carpentry work. Williams soon encountered difficulty in completing its obligations because, in part, the initial price agreed to between the parties was too low. When Roffey became concerned that it would face liability to the owners for failure to complete the project on time, it agreed to pay Williams $£ 10,300$ for its work, in addition to the initial contract price of $£ 20,000$. In short, the contract was varied without any fresh promise coming from Williams to support the promise of Roffey to pay more.

The court found, however, that a contractual variation could be supported by the practical benefits accruing to the promisor in the following circumstances:

[T]he present state of the law on this subject can be expressed in the following propositions: (i) if $A$ has entered into a contract with B to do work for, or to supply goods or services to, B in return for payment by $B$ and (ii) at some stage before $A$ has completely performed his obligations under the contract $B$ has reason to doubt whether $A$ will, or will be able to, complete his side of the bargain and (iii) $B$ thereupon promises $A$ an additional payment in return for A's promise to perform his contractual obligations on time and (iv) as a result of giving his promise B obtains in practice a benefit, or obviates a disbenefit, and (v) B's promise is not given as a result of economic duress or fraud on the part of A, then (vi) the benefit to B is capable of being consideration for B's promise, so that the promise will be legally binding. ${ }^{13 s}$

The benefits in this case, though not expressly identified as such by the court, seem to have been twofold: first, the contractor did not have to incur a late-completion penalty with the owner and second, it did not have to go to the trouble and expense of replacing Williams with another subcontractor. ${ }^{156}$

There is, at date of writing, no Canadian case which has considered Roffey ${ }^{157}$ and only one other which was prepared to entertain "practical benefits" as a reason for enforcing a promise which was otherwise unsupported by fresh consideration. ${ }^{158}$ It is therefore difficult, at this point, to predict the future of Roffey in Canada. ${ }^{159}$ However, it can be observed that the English Court of Appeal's approach - while at odds with the analysis in Gilbert Steel ${ }^{160}$ - is persuasive, practical, and consistent with the parties' intention at the time of entering into the variation, as well as being aligned with modern trends to enforce reasonable expectations.

there must still be but in my judgment the courts nowadays should be more ready to find its existence so as to reflect the intention of the parties to the contract where the bargaining powers are not unequal and where the finding of consideration reflects the true intention of the parties.

Ibid. at 518.

QL search September 9, 1996.

Robichaud, supra note 86.

For a comment on Roffey, see D. Halyk, "Consideration, Practical Benefits and Promissory Estoppel: Enforcement of Contract Modification Promises in Light of Williams v. Roffey Brothers" (1991) 55 Sask. L. Rev. 393.

Supra note 90. 


\section{CONCLUSION}

Over the years since the opening of the Faculty of Law, the doctrine of consideration has lost some of its dominance because, for reasons already explored, the courts are increasingly willing to enforce promises based on reasonable reliance. That said, one cannot agree that Gilmore's bold assertion that "Contract is dead," to Canada, nor that we have "witnessed the dismantling of the formal system of the classical theorists." ${ }^{161}$ On numerous occasions, the Supreme Court of Canada has demonstrated that the bargain theory of consideration "is still the law of Canada." ${ }^{162}$ Furthermore, as inroads on the doctrine of consideration are expressly and mandatorily tied to equity, unconscionability, and the parties' intentions, reliance cannot overwhelm the role of consideration in the enforcement of most promises.

Collins' assessment of the matter is, therefore, more accurate and tempered: the reliance model of liability is not a "minor supplement used to enforce an anomalous collection of donative promises"163 but, rather, a "subsidiary test of liability in the arena of market transactions." ${ }^{164}$ Consistent with the equitable and communitarian values which inform it, the reliance model reflects the "increasing interdependence among the members of society"165 and, by becoming a common basis for liability by the end of the twentieth century, effectively mitigates many of the harsh outcomes which nineteenth century bargain theory produced. 